Systematic Review

\title{
The Association of rs4753426 Polymorphism in the Melatonin Receptor 1B (MTNR1B) Gene and Susceptibility to Adolescent Idiopathic Scoliosis: A Systematic Review and Meta-analysis
}

Peng Yang, MD, Hao Liu, MD, Jun Lin, MD, PhD and Huilin Yang, MD, PhD

From: Department of Orthopaedic Surgery The First Affiliated Hospital of Soochow University 188 Shizi Street, Suzhou, Jiangsu,

China

Address Correspondence: Huilin Yang, MD, PhD Department of Orthopaedic Surgery

The First Affiliated Hospital of Soochow University 188 Shizi Street, Suzhou Jiangsu 215006, China E-mail:

hlyangsuzhou@gmail.com:

Disclaimer: This study is supported by grants from National Nature Science Foundation of China, Jiangsu Provincial Special Program of Medical Science (BL2012004), Jiangsu Provincial Clinical Orthopedic Center, the Priority Academic Program Development

of Jiangsu Higher Education Institutions (PAPD).

Manuscript received: 03-06-2015 Accepted for publication: 04-14-2015

Free full manuscript: www.painphysicianjournal.com
Background: Adolescent idiopathic scoliosis (AIS) is a tridimensional structural deformity of the spine that may deteriorate progressively, leading to significant functional limitations and pain problems. Several previous studies have implicated the rs4753426 single nucleotide polymorphism in the melatonin receptor 1B (MTNR1B) gene in the etiology of AIS. However the sample sizes were limited and the findings of those studies were inconsistent. An overall assessment of the evidence supporting this association has not been previously conducted.

Objectives: To provide a comprehensive assessment and synthesis of the currently available evidence on the association between rs4753426 and AIS.

Study Design: A systematic review and meta-analysis

Setting: University hospital, China.

Methods: This review followed the Preferred Reporting Items for Systematic Review and MetaAnalyses guidelines. PubMed (MEDLINE), EMBASE, Scopus databases, and WANFANG databases were systematically searched through December 2014 to identify relevant studies following a sensitive strategy. Statistical analysis was performed using the Review Manager 5.2 software. Summary odds ratios (ORs) and corresponding 95\% confidence intervals (Cls) were estimated using the fixed-effect inverse variance model for allelic (C vs. T) and genotypic comparisons.

Results: Four papers including 5 studies which involved 2,552 AIS cases and 2,738 controls were identified for this meta-analysis. The results showed that $C$ allele of the rs4753426 was significantly associated with AIS (OR $=1.12,95 \% \mathrm{Cl}: 1.03-1.21, P=0.01)$. CT and CC genotypes were $26 \%(\mathrm{OR}=1.26,95 \% \mathrm{Cl}: 1.04-1.53, P=0.01)$ and $28 \%(\mathrm{OR}=1.28,95 \% \mathrm{Cl}: 1.05-1.56$ $P=0.01)$, respectively, more likely to have AIS compared with CC genotype. As for the dominant model $(C C+T T$ vs. TT), summary ORs showed statistically significant association with AIS (OR = $1.28,95 \% \mathrm{Cl}: 1.06-1.53, P=0.009)$. Compared with the CT+TT genotype, the summary ORs of the CC genotype showed marginally statistically significant association with AIS (OR $=1.11,95$ $\% \mathrm{Cl}: 0.99-1.24, P=0.07)$. The subgroup meta-analysis results showed the $C$ allele and each genotype were significantly associated with AIS in the Asian group but not in the Caucasian group.

Limitations: Paucity of available literature.

Conclusions: To our knowledge, there has been no meta-analysis to analyze the association between rs4753426 polymorphism in the MTNR1B gene and AIS. This systematic review was a comprehensive analysis of the currently available evidence, and found an overall significant association of rs 4753426 polymorphism with the risk of AIS, especially in the Asian population. Further investigation of this association is necessary in other populations.

Key words: Adolescent idiopathic scoliosis, MTNR1B, Rs4753426, single nucleotide polymorphism, occurrence, curve severity, meta-analysis

Pain Physician 2015; 18:419-431 
A dolescent idiopathic scoliosis (AIS) is a complex, tridimensional structural deformity of the spine that most commonly occurs in girls at the peripubertal period (between 10 and 16 years of age) (1). Scoliosis may deteriorate progressively leading to significant functional limitations and cosmetic problems. Using a Cobb angle greater than $10^{\circ}$ as the diagnostic criterion $(2,3)$, the prevalence of AIS has been reported at $1-4 \%$ in the population $(4,5)$, and higher in females, particularly in more severe cases (6).

Despite a number of clinical and epidemiological studies, the etiology and pathogenesis of AIS has not been established. Some hypotheses have been proposed that AIS is associated with abnormal growth, genetic factors, hormonal disturbance, and developmental neuromuscular dysfunction $(7,8)$. Currently, it is thought to be a multifactorial disorder in which genetic or hereditary factors could play a significant role (9-11). Several studies reported possible loci in the familial form of AIS (12-14). Miller et al (15) analyzed 202 families and 1,198 individuals recently, and identified several potential candidate regions, indicating multiple potential predisposition genes that might contribute to AIS.

Melatonin is a hormone created by the pineal gland (16). Since Thillard (17) has reported that pinealectomy of chickens induced severe scoliosis, an involvement of the melatonin signaling pathway dysfunction in AIS has been investigated. Melatonin exerts its biologic effects primarily through 2 transmembrane receptors: melatonin receptor 1A (MTNR1A) and melatonin receptor 1B (MTNR1B), and they have been cloned and characterized, respectively (18). Previous study of MTNR1A showed no association with AIS (19), so a number of studies were conducted to investigate the influence of MTNR1B gene on AIS risk.

The rs4753426 single nucleotide polymorphism (SNP), an C-to-T nucleotide substitution iiop of the melatonin receptor 1B (MTNR1B) gene, has been associated with the risk of AIS (20). It is located in the regulatory region of MTNR1B. However, these published studies have yielded contradictory results rather than conclusive evidence. Some studies showed a significant association (20), while others revealed no evidential association (21-23). A individual study might be unable to detect the true association due to the small effect of the polymorphism on AIS risk. A meta-analysis can be performed to increase the statistical power of the association analysis and obtain a more precise estimate of effect size compared to individual studies (24). Therefore, to derive the currently available evidence between the rs4753426 in the MTNR1B gene and AIS, we conducted a systematic review and meta-analysis.

\section{Methods}

This systematic review and meta-analysis conformed to the Preferred Reporting Items for Systematic Review and Meta-Analyses (PRISMA) guidelines (25). An unpublished protocol was prepared for internal comment.

\section{Search Strategy}

PubMed (MEDLINE), EMBASE, Scopus databases, and WANFANG databases were searched for articles published up to December, 2014 using the following keyword search string: (scoliosis OR AIS) AND (MTNR1B OR nelatonin receptor $1 B$ OR melatonin receptor 2 OR rs4753426 OR MT2) AND (polymorphism OR variant OR mutation). Reference lists of included studies were inspected for additional relevant studies. No language or publication date restrictions were applied. For these articles involving more than one stage groups, each group was included separately. Two reviewers (Peng Yang and Jun Lin) independently screened all citations and abstracts identified to identify potentially eligible studies.

\section{Inclusion/Exclusion Criteria}

Studies were included in the current meta-analysis if they met the following inclusion criteria: (1) casecontrol design; (2) evaluation of the association of MTNR1B polymorphism and AIS; (3) diagnosis of AIS by a spinal expert, confirmed on the basis of clinical and/or radiologic examinations; and (4) the allele distributions in the study meet the Hardy-Weinberg equilibrium (HWE). Studies providing insufficient data, contrary to the inclusion criteria, and duplicate publications were excluded.

\section{Methodological Quality Assessment}

The methodological quality of studies was assessed independently by 2 reviewers (Peng Yang and Jun Lin) using a modified version of the Newcastle-Ottawa Scale (NOS) for observational studies. Disagreements between reviewers were resolved by discussion until consensus was reached. The total score of each trial obtained was expressed as a percentage of the highest scores of all items counted. The trials were deemed to have adequate quality when a quality score was over $50 \%$. 


\section{Data Extraction}

Data abstraction was conducted independently by 2 reviewers (Peng Yang and Jun Lin), with any discrepancies resolved by discussion and consensus. Information extracted on each eligible study included authors, publication year, participants (such as age, sample size, gender), country where the study was conducted, population ethnicity, study design, diagnostic criteria, case and control selection criteria, genotyping method, and MTNR1B genotype counts in AIS and controls. If data were insufficient in the studies, we attempted to contact the authors for further details.

\section{Statistical Analysis}

Meta-analysis was performed using Review Manager 5.2 (Nordic Cochrane Centre, Cochrane Collaboration, Copenhagen, Sweden). All of the data in the studies are dichotomous data expressed as odds ratios (ORs) with 95\% confidence intervals (Cls) to assess the association between MTNR1B gene polymorphism and AIS. Summary ORs were estimated using the fixed-effect inverse variance analysis method for the allelic comparison (C vs. T) and genotypic comparisons of codominant (CC vs. TT and CT vs. TT), dominant (CC + CT vs. TT), and recessive (CC vs. CT + TT) genetic models, where the $C$ allele was considered the risk allele. Between-study heterogeneity was assessed using the 12 statistic and Chi square, with significance set at $P<0.10$. If heterogeneity was not statistically significant and the value of 12 was less than $50 \%$, the fixed-effects model was used to estimate the pooled OR. Alternately, the random-effects model was used. The HWE was evaluated by Fisher's exact test, with significance set at $P<0.05$. Sensitivity analysis was performed to check the robustness of the meta-analysis findings. Funnel plots were examined for evidence of publication bias if sufficient studies were included for meta-analysis $(n \geq 10)(26)$. The overall effect was tested by $Z$ test (significance set at $P<0.05$ ).

\section{Results}

\section{Study Inclusion and Characteristics}

The results of the search criteria and selection of trials for inclusion are shown in a flow diagram of study selection as recommended by Preferred Reporting Items for Systematic Reviews and Meta-analysis (PRISMA). Fig. 1 provides a summary of the study identification and selection process.

Overall, a total of 25 articles was identified. After scanning the titles and abstracts, 4 studies $(20,22,27,28)$, which involved 2,552 AIS patients and 2,738 controls, examining the association between rs4753426 and AIS met the inclusion criteria for this review. One otherwise eligible study was excluded from review for not reporting the allele/genotype frequency distributions (21). Two studies were conducted in Chinese populations $(20,28)$, one in a Japanese population $(22)$, and one in a Hungarian Caucasian population (27). Three studies recruited only female cases and controls $(20,22)$, whereas the other 2 studies were unknown $(27,28)$. The baseline characteristics and allele/genotype frequencies of included studies in this meta-analysis are presented in Tables 1 and 2, respectively. The genotype frequencies of rs4753426 in AIS and control groups followed HWE in all studies.

\section{Meta-analysis Results}

Overall, 4 papers including 5 studies investigated the association of C allele in rs4753426 with AIS susceptibility. ORs and 12 statistics for the overall analysis are presented in Table 3. The results of the meta-analysis showed that the $C$ allele of the MTNR1B rs4753426 was significantly associated with increased AIS risk (OR = 1.12, 95\% Cl: $1.03-1.21, \mathrm{P}=0.01$; Fig. 2). Meta-analysis found a highly statistically significant association between the rs4753426 SNP and AIS for the allelic and genotypic comparisons. On the basis of ethnicity, the 5 studies were divided into 2 subgroups: Asian group and Caucasian group. The subgroup meta-analysis results showed $\mathrm{C}$ allele was significantly associated with AIS in the Asian group (OR $=1.13,95 \% \mathrm{Cl}: 1.03-1.23, \mathrm{P}$ $=0.006$ ), but not in the Caucasian group ( $O R=0.96$, $95 \% \mathrm{Cl}: 0.70-1.31, \mathrm{P}=0.78)$. Compared with the TT genotype, summary ORs suggest that the CT genotype was $26 \%$ more likely to have AIS (OR $=1.26,95 \% \mathrm{Cl}$ : $1.04-1.53, P=0.01$; Fig. 3), and the pooled OR of the genotypes (GG) also showed a statistically significant association with AIS in the Asian group (OR $=1.24,95 \%$ $\mathrm{Cl}: 1.01-1.53, \mathrm{P}=0.04$ ), but not in the Caucasian group (OR $=1.38,95 \% \mathrm{Cl}: 0.80-2.37, \mathrm{P}=0.25)$. Compared with the TT genotype, the CC genotype were $28 \%$ more likely to have AIS (OR $=1.28,95 \% \mathrm{Cl}: 1.05-1.56$, $P=0.01$; Fig. 4), and when stratifying for ethnicity, the pooled OR also showed a statistically significant association with AIS in the Asian group (OR = 1.33, 95\% Cl: $1.08-1.63, P=0.007)$, but not in the Caucasian group (OR $=0.88,95 \% \mathrm{Cl}: 0.45-1.71, \mathrm{P}=0.71)$. As for the dominant model (CC + TT vs. TT), summary ORs showed a statistically significant association with AIS in the Asian group $(\mathrm{OR}=1.28,95 \% \mathrm{Cl}: 1.06-1.53, \mathrm{P}=0.009$; 


\section{PRISMA 2009 Flow Diagram}

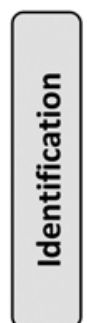

Records identified through database searching $(n=24)$
Additional records identified through other sources

$$
(n=4)
$$

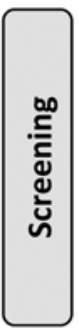

Records after duplicates removed

$(n=3)$

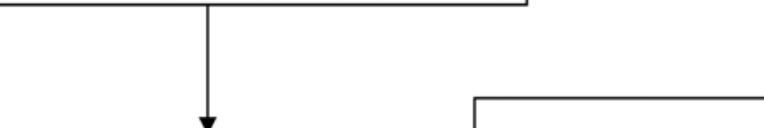

Records excluded $(n=20)$ :

Records screened

$(n=25)$

1.not case-control study $(n=16)$

2.rs4753426 not investigated $(n=3)$

4.Abstract, or proceeding $(n=1)$

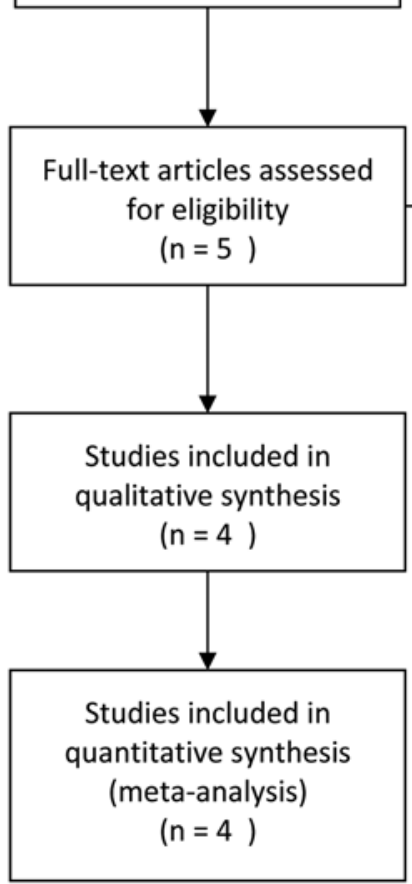

Full-text articles excluded $(n=1)$ : No genotype frequency distribution

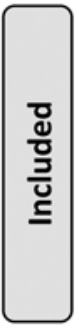

From: Moher D, Liberati A, Tetzlaff J, Altman DG, The PRISMA Group (2009). Preferred Reporting /tems for Systematic Reviews and MetaAnalyses: The PRISMA Statement. PLoS Med 6(6): e1000097. doi:10.1371/journal.pmed1000097

For more information, visit www.prisma-statement.org.

Fig. 1. Flow diagram of the study identification and selection process. 
Table 1. Characteristics of studies included in the meta-analysis.

\begin{tabular}{|c|c|c|c|c|c|c|c|}
\hline \multirow{2}{*}{ Study } & \multirow{2}{*}{ Year } & \multirow{2}{*}{ Genotyping } & \multirow{2}{*}{\multicolumn{2}{|c|}{ Case characteristics }} & \multirow{2}{*}{$\begin{array}{l}\text { Control } \\
\text { characteristics }\end{array}$} & \multicolumn{2}{|l|}{ Subject selection criteria } \\
\hline & & & & & & Case & Control \\
\hline \multirow[t]{2}{*}{ Qiu et al (20) } & \multirow[t]{2}{*}{2007} & \multirow[t]{2}{*}{ PCR-RFLP } & Stage I: & $\begin{array}{l}\mathrm{n}=472 ; \\
\text { females; } \\
\text { age range } \\
10-18 \\
\text { years; } \\
\text { Chinese }\end{array}$ & $\begin{array}{l}\mathrm{n}=304 ; \\
\text { females; } \\
\text { age range } 10-18 \\
\text { years; } \\
\text { Chinese }\end{array}$ & $\begin{array}{l}\text { The diagnosis was confirmed } \\
\text { clinically and radiologically; } \\
\text { Only patients with Cobb angle }>20^{\circ} \\
\text { with a rotational prominence } \\
\text { No congenital scoliosis, } \\
\text { neuromuscular scoliosis, scoliosis } \\
\text { with skeletal dysplasia, or scoliosis } \\
\text { with known endocrine and } \\
\text { connective tissue abnormalities, or } \\
\text { prior treatment for scoliosis. }\end{array}$ & $\begin{array}{l}\text { Healthy volunteers } \\
\text { Clinically } \\
\text { examined }\end{array}$ \\
\hline & & & Stage II: & $\mathrm{n}=342$ & $\mathrm{n}=347$ & $\begin{array}{l}\text { A separate additional sample of } \\
\text { AIS }\end{array}$ & $\begin{array}{l}\text { A sample of } \\
\text { archival umbilical } \\
\text { cord bloods }\end{array}$ \\
\hline Qiu et al (28) & 2009 & PCR-RFLP & \multicolumn{2}{|c|}{$\begin{array}{l}\mathrm{n}=814 \\
\text { age and sex unknown; } \\
\text { Chinese }\end{array}$} & $\begin{array}{l}\mathrm{n}=651 ; \\
\text { age and sex } \\
\text { unknown; } \\
\text { Chinese }\end{array}$ & $\begin{array}{l}\text { The diagnosis was confirmed } \\
\text { clinically and radiologically; } \\
\text { Only patients with Cobb } \\
\text { angle }>20^{\circ} \text {. } \\
\text { No congenital scoliosis, } \\
\text { neuromuscular scoliosis, scoliosis } \\
\text { with skeletal dysplasia, or scoliosis } \\
\text { with known endocrine and } \\
\text { connective tissue abnormalities, or } \\
\text { prior treatment for scoliosis. }\end{array}$ & $\begin{array}{l}\text { Examined with } \\
\text { forward bending } \\
\text { test to rule out } \\
\text { scoliosis and } \\
\text { confirmed by } \\
\text { radiograph if } \\
\text { test result was } \\
\text { uncertain }\end{array}$ \\
\hline $\begin{array}{l}\text { Takahashi et } \\
\text { al (22) }\end{array}$ & 2011 & $\begin{array}{l}\text { PCR-based } \\
\text { Invader } \\
\text { assay }\end{array}$ & \multicolumn{2}{|c|}{$\begin{array}{l}\mathrm{n}=798 ; \\
\text { female; } \\
\text { mean age } 17.7 \pm 5.8 \\
\text { years; } \\
\text { Japanese }\end{array}$} & $\begin{array}{l}\mathrm{n}=1239 ; \\
\text { female; } \\
\text { mean age } \\
63.7 \pm 13.8 \text { years; } \\
\text { Japanese }\end{array}$ & $\begin{array}{l}\text { Diagnosis based on clinical and } \\
\text { radiological examination; } \\
\text { Cobb angle } \geq 15^{\circ} \text {; } \\
\text { not congenital, juvenile, and adult- } \\
\text { onset scoliosis or secondary AIS }\end{array}$ & $\begin{array}{l}602 \text { patients with } \\
\text { knee osteoarthritis, } \\
85 \text { patients with } \\
\text { ossification of } \\
\text { the posterior } \\
\text { longitudinal } \\
\text { ligament but } \\
\text { without scoliosis, } \\
\text { and } 552 \text { healthy } \\
\text { females }\end{array}$ \\
\hline $\begin{array}{l}\text { Morocz et al } \\
(27)\end{array}$ & 2011 & PCR-RFLP & \multicolumn{2}{|c|}{$\begin{array}{l}\mathrm{n}=126 ; \\
\text { Sex unknown; } \\
\text { mean age } 16.8 \pm 3.1 \\
\text { years; } \\
\text { Caucasian }\end{array}$} & $\begin{array}{l}\mathrm{n}=197 \\
\text { Sex unknown; } \\
\text { mean age } 16.8 \pm \\
3.1 \text { years; } \\
\text { Caucasian }\end{array}$ & $\begin{array}{l}\text { The diagnosis was confirmed } \\
\text { clinically and radiologically; } \\
\text { The mean value of Cobb angles } \\
\text { was } 64.7 \pm 19.2^{\circ} \\
\text { The curve pattern of AIS was } \\
\text { defined mostly right thoracic curve, } \\
\text { thoracolumbar curve, left lumbar } \\
\text { curve, and double major curves. }\end{array}$ & $\begin{array}{l}\text { Control patients } \\
\text { matching the cases } \\
\text { for age and sex } \\
\text { without clinical } \\
\text { evidence of } \\
\text { scoliosis }\end{array}$ \\
\hline
\end{tabular}

AIS adolescent idiopathic scoliosis, PCR-RFLP PCR-restriction fragment length polymorphism

Fig. 5), but not in the Caucasian group (OR $=1.21,95 \%$ $\mathrm{Cl}: 0.72-2.02, P=0.47)$. Compared with the $\mathrm{CT}+\mathrm{TT}$ genotype, the summary ORs of CC genotype showed marginally statistically significant association with AIS (OR = 1.11, $95 \% \mathrm{Cl}: 0.99-1.24, P=0.07)$. The pooled OR showed statistically significant association with AIS in Asian group (OR = 1.13, $95 \% \mathrm{Cl}: 1.01-1.27, P=0.03$ ), but not in Caucasian group (OR $=0.71,95 \% \mathrm{Cl}$ : 0.41-1.23),
$P=0.22$ ). The pooled ORs and $95 \% \mathrm{Cls}$ on the association between rs4753426 and AIS for the overall analysis are presented in Table 3. No substantial between-study heterogeneity was detected among the comparisons, so heterogeneity was not found to be a concern. A sensitivity analysis was performed and confirmed the stability of the association. After omitting any research and calculating the overall estimate for the remaining 
Table 2. Genotype distributions of studies included in the meta-analysis.

\begin{tabular}{|c|c|c|c|c|c|c|c|c|c|c|c|c|c|c|c|}
\hline \multirow{3}{*}{ Study } & \multirow{3}{*}{ Year } & \multirow{3}{*}{ Country } & \multirow{3}{*}{ Ethnicity } & \multicolumn{6}{|c|}{ Case } & \multicolumn{6}{|c|}{ Control } \\
\hline & & & & \multirow{2}{*}{$\begin{array}{c}\text { Sample } \\
\text { size }\end{array}$} & \multicolumn{3}{|c|}{ Genotypes } & \multirow{2}{*}{$\mathbf{C}$} & \multirow{2}{*}{$\mathbf{T}$} & \multirow{2}{*}{$\begin{array}{c}\text { Sample } \\
\text { size }\end{array}$} & \multicolumn{3}{|c|}{ Genotypes } & \multirow{2}{*}{$\mathbf{C}$} & \multirow{2}{*}{$\mathbf{T}$} \\
\hline & & & & & $\mathrm{CC}$ & CT & TT & & & & $\mathbf{C C}$ & CT & TT & & \\
\hline 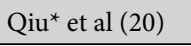 & 2007 & China & Asian & 472 & 239 & 202 & 31 & 680 & 264 & 304 & 129 & 151 & 24 & 409 & 199 \\
\hline $\mathrm{Qiu}^{* *}$ et al (20) & 2007 & China & Asian & 342 & 184 & 136 & 22 & 504 & 180 & 347 & 171 & 138 & 38 & 480 & 214 \\
\hline Qiu, et al (28) & 2009 & China & Asian & 814 & 423 & 338 & 53 & 1184 & 444 & 651 & 300 & 289 & 62 & 889 & 413 \\
\hline $\begin{array}{l}\text { Takahashi, et } \\
\text { al (22) }\end{array}$ & 2011 & Japan & Asian & 798 & 339 & 372 & 87 & 1050 & 546 & 1239 & 545 & 548 & 146 & 1638 & 840 \\
\hline $\begin{array}{l}\text { Morocz, et al } \\
(27)\end{array}$ & 2011 & Hungary & Caucasian & 126 & 24 & 72 & 30 & 120 & 132 & 197 & 49 & 94 & 54 & 192 & 202 \\
\hline
\end{tabular}

Table 3. The pooled ORs and 95\% CIs on the association between rs4753426 and AIS.

\begin{tabular}{|l|c|c|c|c|c|c||}
\hline \multirow{2}{*}{ Comparison } & \multicolumn{2}{|c|}{ Asian } & \multicolumn{2}{c|}{ Caucasian } & \multicolumn{2}{c||}{ Summary } \\
\cline { 2 - 8 } & OR(95\% CIs) & $\boldsymbol{P}$ & OR(95\% CIs) & $\boldsymbol{P}$ & OR(95\% CIs) & \multicolumn{1}{|c|}{} \\
\hline C vs. T & $1.13[1.03,1.23]$ & 0.006 & $0.96[0.70,1.31]$ & 0.78 & $1.12[1.03,1.21]$ & 0.01 \\
\hline CT vs. TT & $1.24[1.01,1.53]$ & 0.04 & $1.38[0.80,2.37]$ & 0.25 & $1.26[1.04,1.53]$ & 0.02 \\
\hline CC vs. TT & $1.33[1.08,1.63]$ & 0.007 & $0.88[0.45,1.71]$ & 0.71 & $1.28[1.05,1.56]$ & 0.01 \\
\hline CC+CT vs. TT & $1.29[1.06,1.56]$ & 0.01 & $1.21[0.72,2.02]$ & 0.47 & $1.28[1.06,1.53]$ & 0.009 \\
\hline CC vs. CT+TT & $1.13[1.01,1.27]$ & 0.03 & $0.71[0.41,1.23]$ & 0.22 & $1.11[0.99,1.24]$ & 0.07 \\
\hline
\end{tabular}

CI confidence interval, OR odds ratio

$P$ value corresponding to the $\mathrm{Z}$ test for the summary effect estimate $(P<0.05$ considered statistically significant)

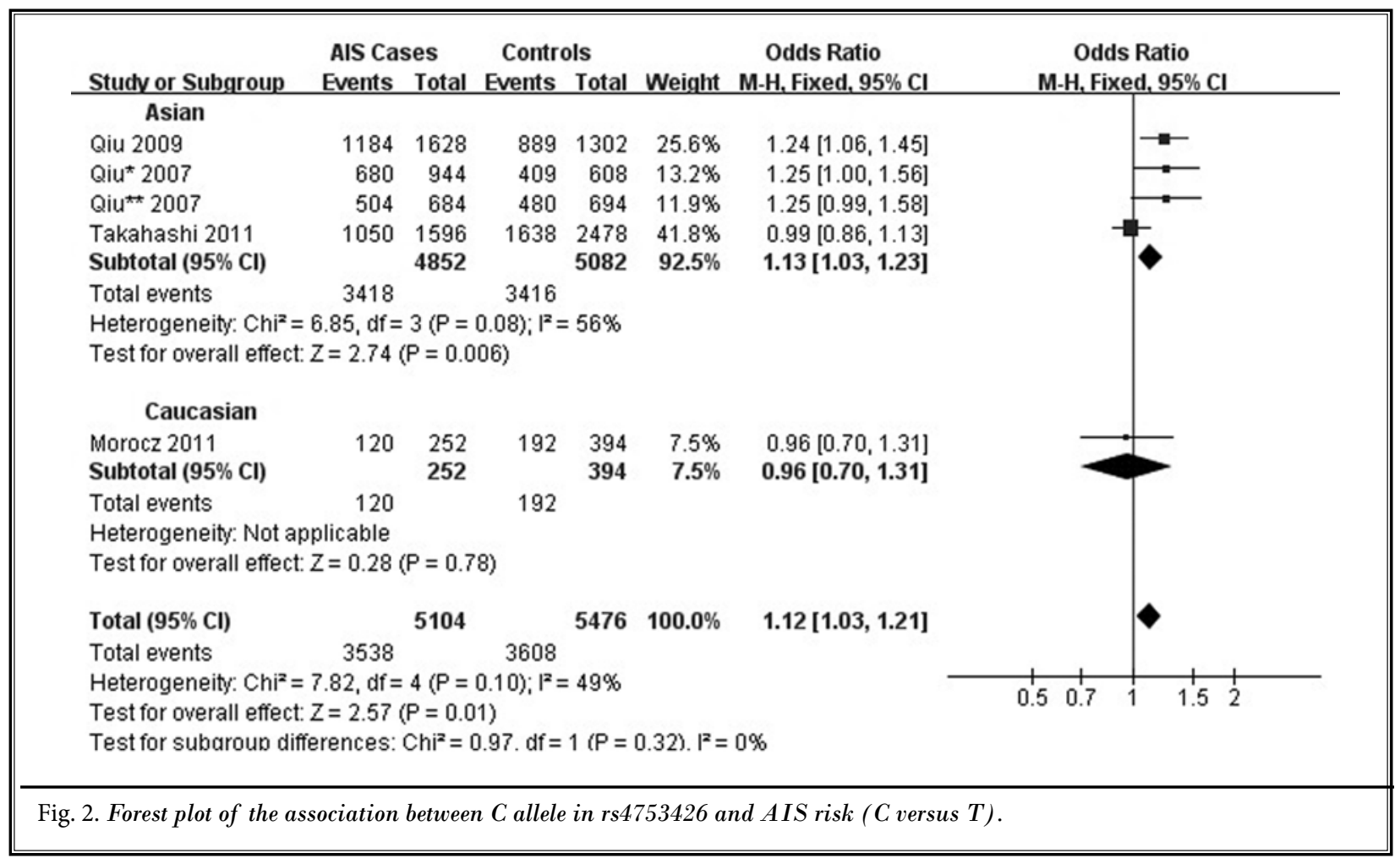


The Association of rs4753426 Polymorphism in the Melatonin Receptor 1B (MTNR1B) Gene

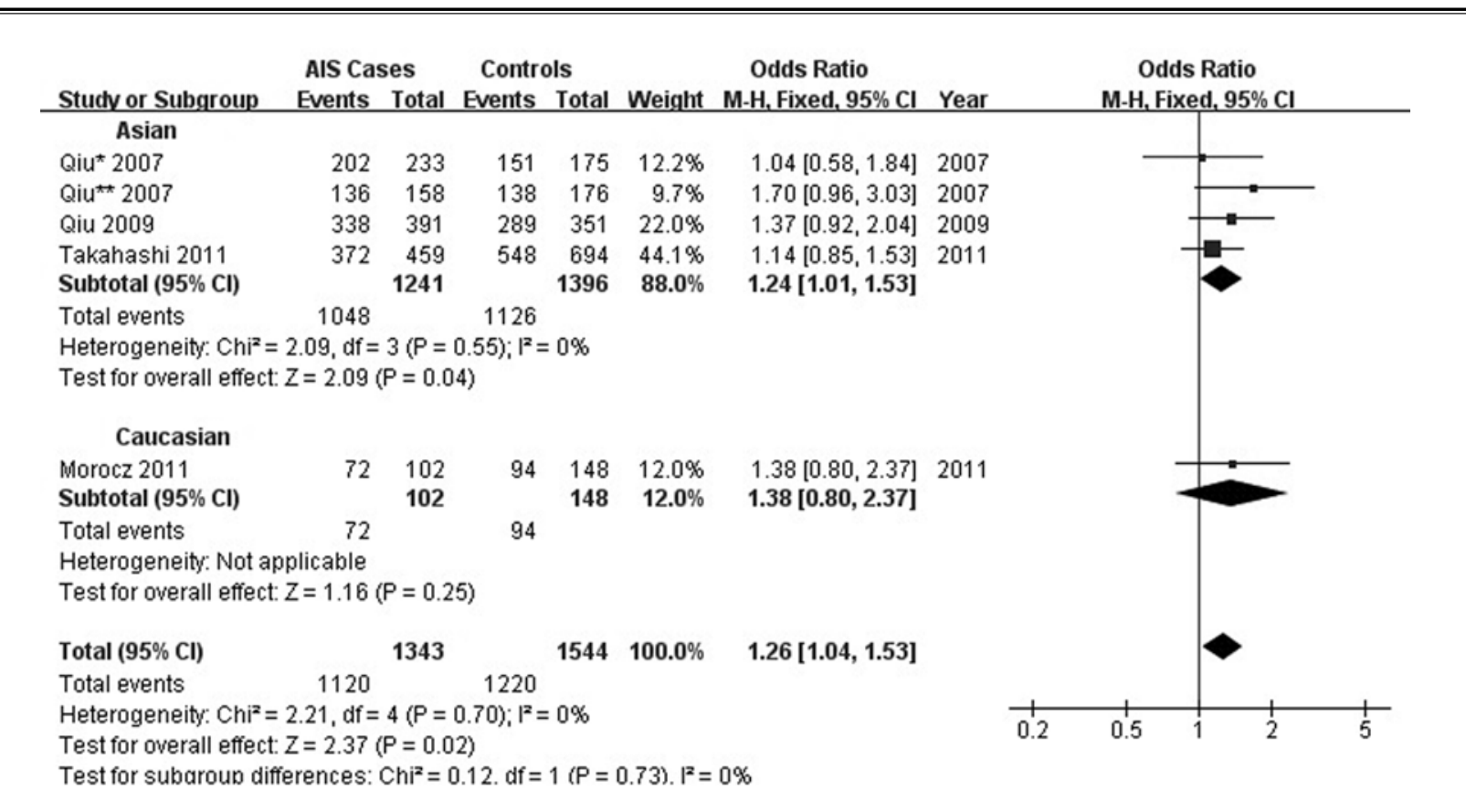

Fig. 3. Forest plot of the association between rs4753426 and AIS for the overall codominant genotypic comparison (CT vs. TT).

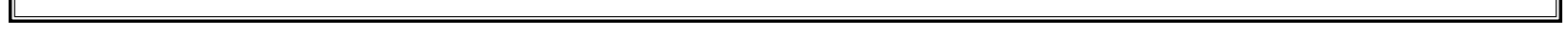

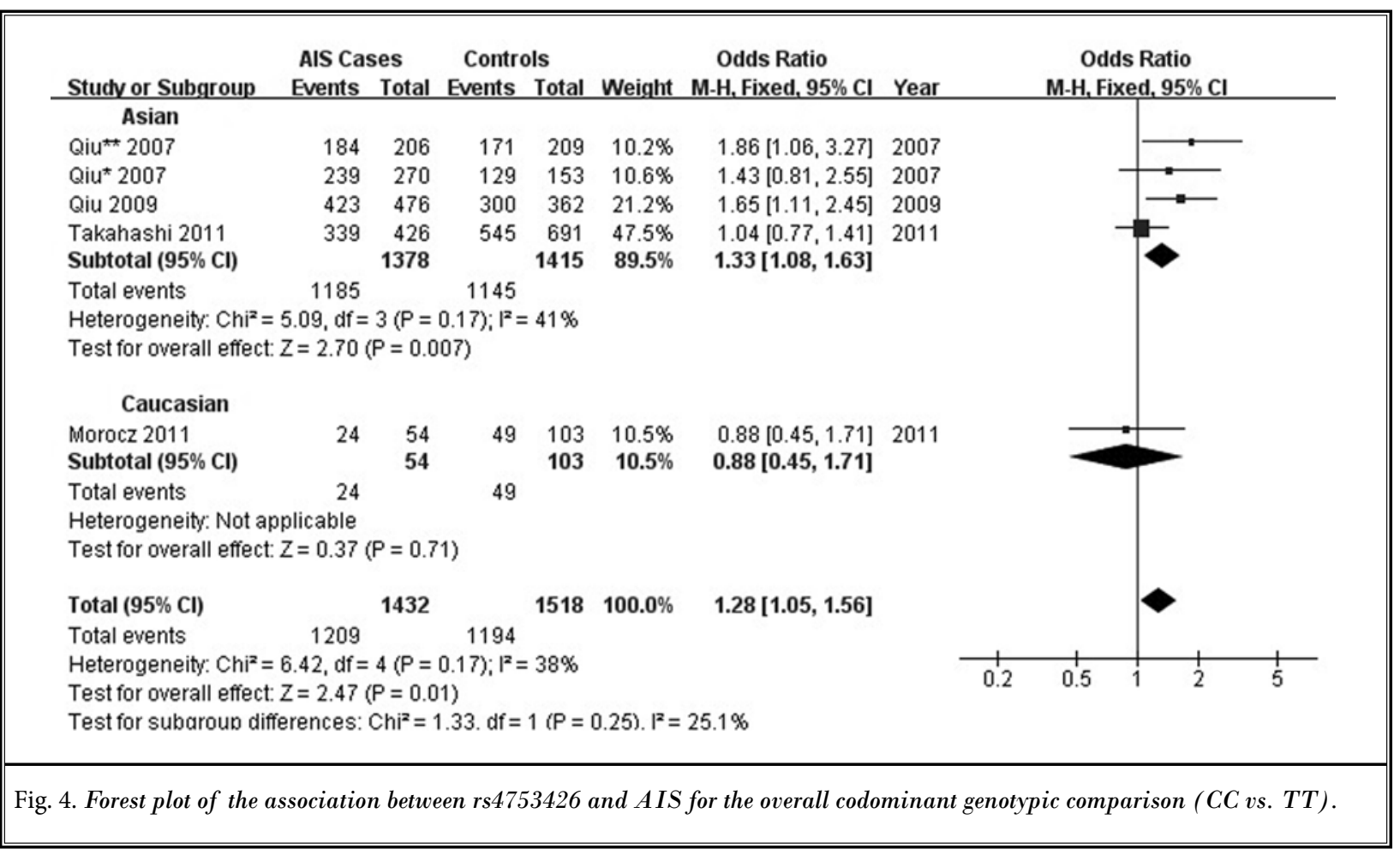




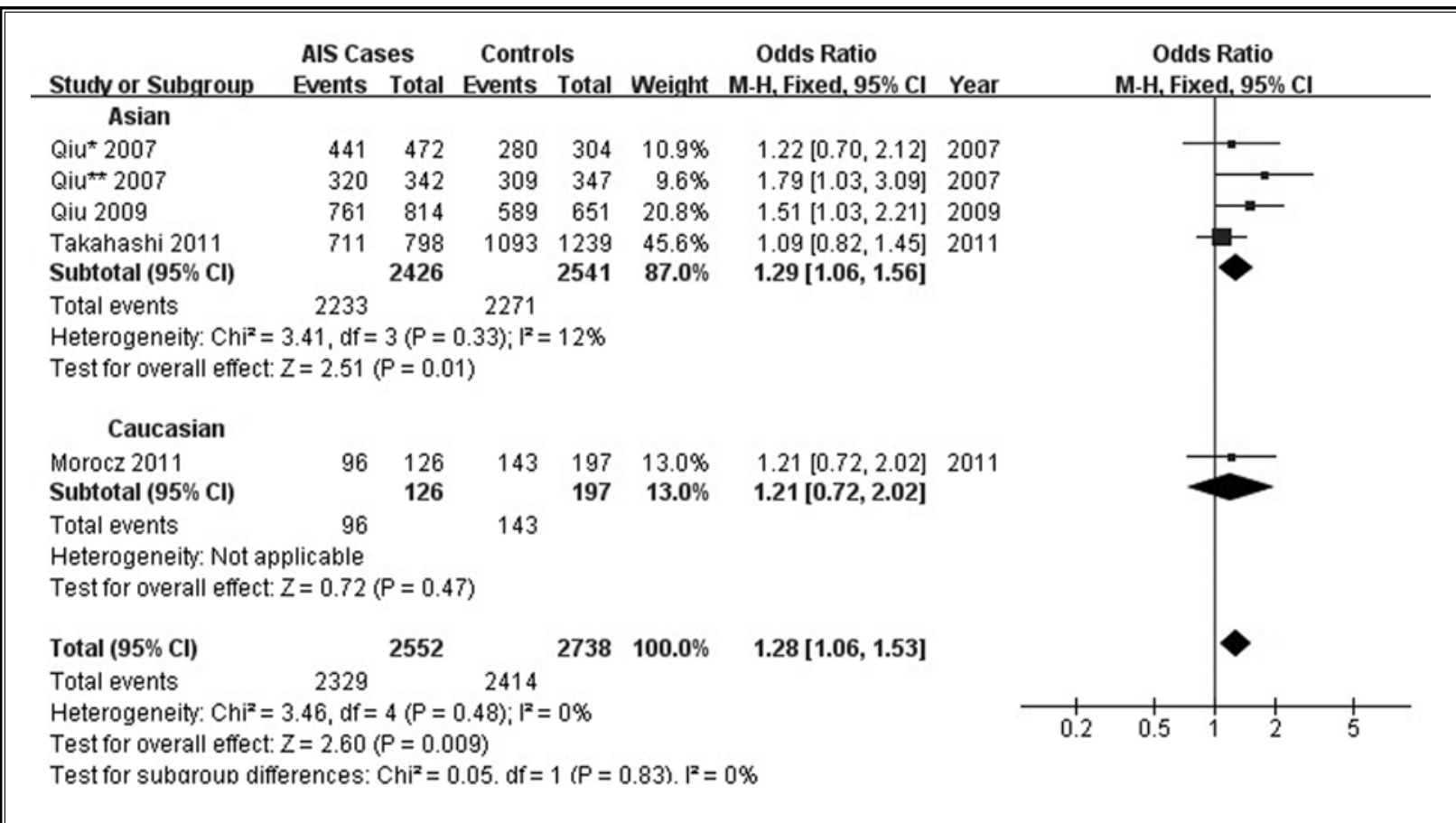

Fig. 5. Forest plot of the association between rs4753426 and AIS for the overall dominant genotypic comparison (CC+CT vs. TT).

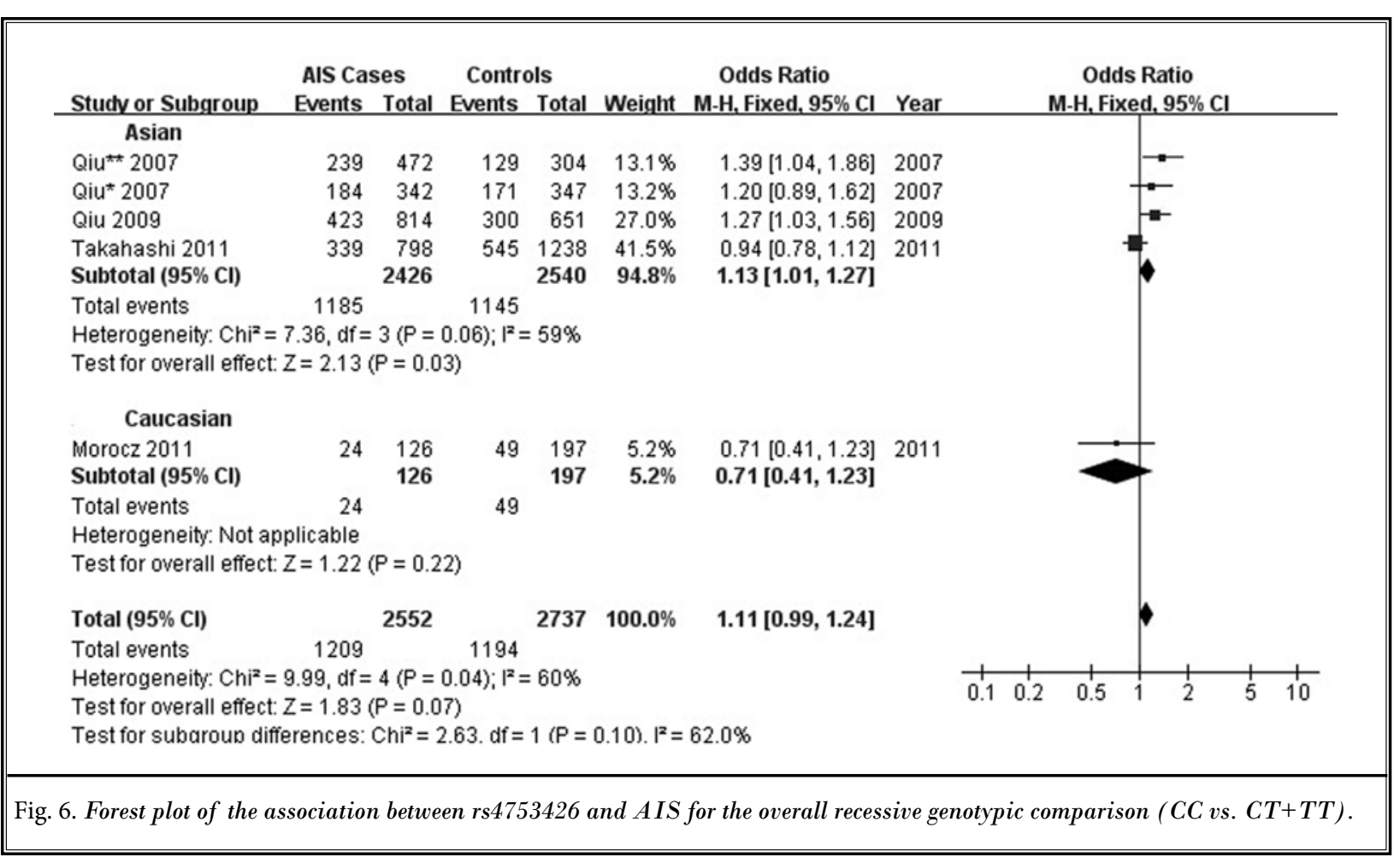


studies, the summary effect did not change. As there are only 5 studies $(<10)$ included in this review, this is an insufficient number for a meaningful interpretation of the funnel plots relating to publication bias.

\section{Discussion}

Despite extensive study, the etiology of AIS remains obscure. Nowadays, it is demonstrated that genetic factors play a significant role in AIS, among which the melatonin signaling pathway has attracted considerable attention. As described in the introduction, preclinical studies in several scoliosis animal models $(17,29)$ indicated the important role of melatonin in development of scoliosis. MTNR1B gene promoter polymorphism may cause a reduced expression of melatonin receptor $1 \mathrm{~B}$, resulting in a functional deficiency of melatonin, and have a potential association with AIS occurrence. As a candidate gene for AIS, Qiu et al (20) performed a 2-stage case-control study and found that rs4753426 in the MTNR1B gene was associated with an individual's susceptibility to AIS in a Chinese population. Subsequent studies $(21,22)$ were unable to replicate the finding and yielded conflicting results. A individual study might be unable to detect the true association due to the small effect of the polymorphism on AIS risk, so this meta-analysis was of great value to obtain a more precise estimate of the association between rs4753426 polymorphism and AIS.

To our knowledge, there has been no metaanalysis to analyze the association between rs4753426 polymorphism in the MTNR1B gene and AIS. The present meta-analysis involving 2,552 AIS cases and 2,738 controls found a highly statistically significant association between the rs4753426 SNP and AIS. Our results showed that carriers of the rs4753426 C allele were at risk of developing AIS. Carriers of the CT and CC genotypes were $26 \%(\mathrm{OR}=1.26,95 \% \mathrm{Cl}: 1.04-1.53, P=$ $0.02)$ and $28 \%(\mathrm{OR}=1.28,95 \% \mathrm{Cl}: 1.05-1.56, P=0.01)$, respectively, more likely to have AIS compared with carriers of the TT genotype. While compared with the CC
+ CT genotype, the result showed that the homozygous TT genotype was a protective factor of developing AIS. As for the genotype (CC vs. CT + TT), the homozygous CC genotype was found to be a risk factor in the Asian group. Subgroup analysis by race suggested that the $C$ allele and genotype $(C C, C T, C C+C T)$ were significantly associated with AIS in the Asian but not in the Caucasian population. Two main reasons may explain this difference in 2 ethnic groups. One reason is the deficiency of the Caucasian study. There are only 2 studies which researched rs4753426 polymorphism in a Caucasian population. One study is included in this meta-analysis, and the other is excluded for not reporting the allele/ genotype frequency distributions. The second reason is that ethnic specificity lead to the differences. The rs4753426 polymorphism may only happen in the Asian population. Future studies are required to explore the ethnic specificity differences in the rs4753426 polymorphisms in other ethnic groups.

Current evidence has confirmed that rs4753426 SNP is not associated with the curve severity in AIS patients. This systematic review and meta-analysis included 3 studies which conducted case-only analysis on skeletally mature subgroups (Table 4). One study was conducted in Japan $(22)$, the others were in China $(20,28)$. Three studies all found no association between rs4753426 SNP and the curve severity in AIS. Besides, Xu et al (30) found that rs4753426 was marginally associated with bracing failure. These clinical correlations may have potential applications in personalized medicine, but currently further studies are needed to confirm the role of rs4753426 in the curve severity, developing, and treatment of AIS.

Although this meta-analysis has a strict and comprehensive process, there are still some potential limitations that should be discussed. First, the completeness of evidence may be influenced by language bias (31) during the study identification process. Publication bias is also a potentially important limitation of this study. We did not assess the publication bias, for the

Table 4. Summary of association findings of the rs4753426 polymorphism with AIS curve severity

\begin{tabular}{|c|c|c|c|c|c|c|c|}
\hline \multirow[b]{2}{*}{ Study } & \multicolumn{2}{|r|}{$\mathbf{C C}$} & \multicolumn{2}{|r|}{ CT } & \multicolumn{2}{|r|}{ TT } & \multirow[b]{2}{*}{$P^{*}$} \\
\hline & $\begin{array}{c}\text { Sample } \\
\text { Size }\end{array}$ & $\begin{array}{c}\text { Mean Cobb Angle } \\
\left({ }^{\circ}\right)(\text { mean } \pm \text { SD })\end{array}$ & $\begin{array}{c}\text { Sample } \\
\text { Size }\end{array}$ & $\begin{array}{l}\text { Mean Cobb Angle } \\
\left({ }^{\circ}\right)(\text { mean } \pm \text { SD })\end{array}$ & $\begin{array}{c}\text { Sample } \\
\text { Size }\end{array}$ & $\begin{array}{c}\text { Mean Cobb Angle } \\
\left({ }^{\circ}\right)(\text { mean } \pm \text { SD })\end{array}$ & \\
\hline Qiu et al (20) & 121 & $38.8 \pm 11.3$ & 99 & $36.1 \pm 15.2$ & 19 & $38.0 \pm 18.7$ & $0.358^{\star}$ \\
\hline Qiu et al (28) & 219 & $37.6 \pm 12.5$ & 176 & $36.7 \pm 13.8$ & 30 & $38.5 \pm 16.5$ & $0.703^{*}$ \\
\hline Takahashi et al (22) & 237 & $49.1 \pm 16.5$ & 240 & $46.0 \pm 16.0$ & 61 & $49.1 \pm 18.3$ & $0.12^{*}$ \\
\hline
\end{tabular}

* Calculated by ANOVA. 
number of included studies $(n<10)$ was insufficient for a meaningful interpretation of the funnel plots relating to publication bias. So, this should be interpreted with caution. Besides, study design, genotyping error, gender, age, and population stratification may cause biases of genetic association. Because all the AIS cases in the studies were from hospitals, the selection bias may exist. Secondly, the included studies in this meta-analysis were from Asian and Caucasian populations. The data about other populations and countries was limited. Considering the diversity and differences between populations in AIS susceptibility because of rs4753426, the present findings in this meta-analysis may not be generalizable. Further studies in other ethnic populations are needed to explore the possibility of ethnic differences between rs4753426 polymorphisms and AIS. Third, the AIS patients in this meta-analysis have different Cobb angles. Qiu et al $(20,28)$ recruited AIS patients with a Cobb angle $>20^{\circ}$, while Takahashi et al (22) recruited AIS patients with a Cobb angle $>15^{\circ}$, and the other study (27) included patients with a mean Cobb angle of $64.7 \pm 19.2^{\circ}$. So patients included in this meta-analysis had different baseline characteristics, which may lead to heterogeneity and affect the result eventually. And last but not least, this meta-analysis only included 4 high-quality studies which may significantly influence the essential association. Despite several potential limitations, the overall quality of this meta-analysis was high. Therefore, the findings of the association of rs4753426 with AIS in the present meta-analysis can be reasonably credible.

\section{Conclusions}

The present systematic review provides a comprehensive evaluation of the available evidence on the association between the rs4753426 SNP and AIS. This meta-analysis found an overall significant association between rs4753426 and AIS, especially in the Asian population. The rs4753426 polymorphism may be used as a prospective predictor of AIS risk especially in the Asian population. The relationship between rs4753426 polymorphism and AIS in other ethnic populations and the impact of this SNP on AIS severity need to be explored in future studies.

\section{Acknowledgments}

This study is supported by grants from National Nature Science Foundation of China, Jiangsu Provincial Special Program of Medical Science (BL2012004), Jiangsu Provincial Clinical Orthopedic Center, the Priority Academic Program Development of Jiangsu Higher Education Institutions (PAPD).

\section{Author Contributions}

Conceived and designed the experiments: YP, LJ, LH. Performed the experiments: YP, LJ, LH.

Analyzed the data: YP, LJ, LH. Contributed reagents/materials/analysis tools: YP, LJ, LH.

Wrote the paper: YP, LJ, LH.

Peng Yang and Hao Liu contributed equally to this work. 


\section{Supplement 1. Modified Newcastle-Ottawa Scale for case-control studies of genetic association}

Note: A study can be awarded a maximum of one star for each numbered item within the Selection and Exposure categories. A maximum of two stars can be given for Comparability.

Selection

1) Is the case definition adequate?

a) yes, with independent validation *

b) yes, e.g. record linkage or based on self-reports

c) no description

2) Representativeness of the cases

a) consecutive or obviously representative series of cases *

b) potential for selection biases or not stated

3) Selection of Controls

a) community controlsandgenetic polymorphism of interest in $\mathrm{HWE}^{\star}$

b) hospital controlsand genetic polymorphism of interest in HWE

c) not community or hospital controls; genetic polymorphism of interest not in HWE

d) no description

4) Definition of Controls

a) no history of disease (endpoint) *

b) no description of source

Comparability

1) Comparability of cases and controls on the basis of the design or analysis

a) cases and controls of homogeneous ethnic descent *

b) no evidence of population stratification *

c) no description

Exposure

1) Ascertainment of exposure

a) used quality control procedures (e.g. reanalysis of random samples, analysis of samples with a different genotyping method, analysis of replicate samples, sequencing)andblinded to phenotype status while genotyping*

b) used quality control procedures, but no reported blinding

c) no report of quality control procedures or blinding

2) Same method of ascertainment for cases and controls

a) yes *

b) no

3) Genotyping call rate

a) $>99 \%$ call rate $*$

b) not reported 
Supplement 2. Quality assessment of studies included in the meta-analysis on the association of rs4753426 with adolescent idiopathic scoliosis using a modified Newcastle-Ottawa Scale

\begin{tabular}{|c|c|c|c|c|}
\hline Study & Qiu et al (20) & Qiu et al (28) & Takahashi et al (22) & Morocz et al (27) \\
\hline \multicolumn{5}{|l|}{ Selection } \\
\hline $\begin{array}{l}\text { Adequacy of } \\
\text { case definition }\end{array}$ & $\begin{array}{l}\text { Multiple processes to ascertain } \\
\text { case status, including reference } \\
\text { to primary record source } \\
\text { (a) }\end{array}$ & $\begin{array}{l}\text { Multiple processes to } \\
\text { ascertain case status, } \\
\text { including reference } \\
\text { to primary record } \\
\text { source (a) }\end{array}$ & $\begin{array}{l}\text { Multiple processes to } \\
\text { ascertain case status, } \\
\text { including reference to } \\
\text { primary record source } \\
\text { (a)* }\end{array}$ & $\begin{array}{l}\text { Multiple processes to } \\
\text { ascertain case status, } \\
\text { including reference to } \\
\text { primary record source } \\
\text { (a)* }\end{array}$ \\
\hline $\begin{array}{l}\text { Representativeness of } \\
\text { the cases }\end{array}$ & $\begin{array}{l}\text { All cases in a defined hospital } \\
\text { (a)* }\end{array}$ & $\begin{array}{l}\text { All cases in a defined } \\
\text { hospital (a)* }\end{array}$ & $\begin{array}{l}\text { All cases in a defined } \\
\text { hospital (a)* }\end{array}$ & $\begin{array}{l}\text { All cases in defined hospitals } \\
\text { (a) }{ }^{*}\end{array}$ \\
\hline Selection of controls & $\begin{array}{l}\text { Community controls and } \\
\text { genetic polymorphism of } \\
\text { interest in HWE }(a)^{*}\end{array}$ & $\begin{array}{l}\text { Hospital controls } \\
\text { and genetic } \\
\text { polymorphism of } \\
\text { interest in HWE (b) }\end{array}$ & $\begin{array}{l}\text { Community controls and } \\
\text { genetic polymorphism of } \\
\text { interest in HWE } \\
\text { (a) }{ }^{*}\end{array}$ & $\begin{array}{l}\text { Community controls and } \\
\text { genetic polymorphism of } \\
\text { interest in HWE } \\
\text { (a)* }\end{array}$ \\
\hline Definition of controls & $\begin{array}{l}\text { No history of AIS } \\
\text { (a) }{ }^{*}\end{array}$ & $\begin{array}{l}\text { No history of AIS } \\
\text { (a) }{ }^{*}\end{array}$ & $\begin{array}{l}\text { No history of AIS } \\
\text { (a) * }\end{array}$ & $\begin{array}{l}\text { No history of AIS } \\
\text { (a) * }\end{array}$ \\
\hline \multicolumn{5}{|l|}{ Comparability } \\
\hline $\begin{array}{l}\text { Cases and controls of } \\
\text { homogeneous } \\
\text { ethnic descent }\end{array}$ & $\begin{array}{l}\text { Homogeneous ethnic descent } \\
\qquad(\mathrm{a})^{*}\end{array}$ & $\begin{array}{l}\text { Homogeneous ethnic } \\
\text { descent (a)* }\end{array}$ & $\begin{array}{l}\text { Homogeneous ethnic } \\
\text { descent (a)* }\end{array}$ & $\begin{array}{l}\text { Homogeneous ethnic } \\
\text { descent (a)* }\end{array}$ \\
\hline $\begin{array}{l}\text { Population } \\
\text { stratification }\end{array}$ & $\begin{array}{l}\text { No description } \\
\text { (c) }\end{array}$ & $\begin{array}{l}\text { No description } \\
\text { (c) }\end{array}$ & $\begin{array}{l}\text { No description } \\
\text { (c) }\end{array}$ & $\begin{array}{l}\text { No description } \\
\text { (c) }\end{array}$ \\
\hline \multicolumn{5}{|l|}{ Exposure } \\
\hline $\begin{array}{l}\text { Ascertainment of } \\
\text { exposure }\end{array}$ & $\begin{array}{l}\text { Quality control; } \\
\text { no report of blinding } \\
\text { (b) }\end{array}$ & $\begin{array}{l}\text { Quality control; } \\
\text { With blinding } \\
\text { (a)* }\end{array}$ & $\begin{array}{l}\text { Quality control; } \\
\text { With blinding } \\
\text { (a)* }\end{array}$ & $\begin{array}{l}\text { Quality control; } \\
\text { With blinding } \\
\text { (a)* }\end{array}$ \\
\hline $\begin{array}{l}\text { Same method of } \\
\text { ascertainment for cases } \\
\text { and controls }\end{array}$ & $\begin{array}{l}\text { Yes } \\
(\text { a) }\end{array}$ & $\begin{array}{l}\text { Yes } \\
(\mathrm{a})^{*}\end{array}$ & $\begin{array}{l}\text { Yes } \\
(\text { a) }\end{array}$ & $\begin{array}{l}\text { Yes } \\
(\text { a) }\end{array}$ \\
\hline Genotyping call rate & $\begin{array}{l}\text { Not reported } \\
\text { (b) }\end{array}$ & $\begin{array}{l}\text { Not reported } \\
\text { (b) }\end{array}$ & $\begin{array}{l}\text { Not reported } \\
\text { (b) }\end{array}$ & $\begin{array}{l}\text { Not reported } \\
\text { (b) }\end{array}$ \\
\hline Total & $* * * * * *(n=6)$ & $* * * * * *(n=6)$ & $* * * * * *(n=7)$ & $* * * * * *(n=7)$ \\
\hline
\end{tabular}




\section{References}

1. Weinstein SL, Dolan LA, Cheng JC, Danielsson A, Morcuende JA. Adolescent idiopathic scoliosis. Lancet 2008; 371:1527-1537.

2. Lonstein JE. Spondylolisthesis in children. Cause, natural history, and management. Spine (Phila Pa 1976) 1999; 24:2640-2648.

3. Trobisch P, Suess O, Schwab F. Idiopathic scoliosis. Dtsch Arztebl Int 2010; 107:875-883, 884 .

4. Lamartina C, Capuzzo A, Cecchinato R, Zerbi A, Berjano P. Adolescent idiopathic scoliosis surgery with patient-specific screw placement-guides. Eur Spine J 2014; 23:2765-2766.

5. Asher MA, Burton DC. Adolescent idiopathic scoliosis: Natural history and long term treatment effects. Scoliosis 2006; 1:2.

6. Rogala EJ, Drummond DS, Gurr J. Scoliosis: Incidence and natural history. A prospective epidemiological study. J Bone Joint Surg Am 1978; 60:173-176.

7. Lowe TG, Edgar M, Margulies JY, Miller $\mathrm{NH}$, Raso VJ, Reinker KA, Rivard $\mathrm{CH}$. Etiology of idiopathic scoliosis: current trends in research. J Bone Joint Surg Am 2000; 82-A:1157-1168.

8. Wei-Jun W, Xu S, Zhi-Wei W, Xu-Sheng Q, Zhen L, Yong Q. Abnormal anthropometric measurements and growth pattern in male adolescent idiopathic scoliosis. Eur Spine J 2012; 21:77-83.

9. Miller $\mathrm{NH}$. Genetics of familial idiopathic scoliosis. Clin Orthop Relat Res 2007; 462:6-10.

10. Wise CA, Barnes R, Gillum J, Herring JA, Bowcock AM, Lovett M. Localization of susceptibility to familial idiopathic scoliosis. Spine (Phila Pa 1976) 2000; 25:2372-2380.

11. Hefti F. Pathogenesis and biomechanics of adolescent idiopathic scoliosis (AIS). J Child Orthop 2013; 7:17-24.

12. Wise CA, Barnes R, Gillum J, Herring JA, Bowcock AM, Lovett M. Localization of susceptibility to familial idiopathic scoliosis. Spine (Phila Pa 1976) 2000; 25:2372-2380.
13. Justice CM, Miller NH, Marosy B, Zhang J, Wilson AF. Familial idiopathic scoliosis: Evidence of an X-linked susceptibility locus. Spine (Phila Pa 1976) 2003; 28:589-594.

14. Chan V, Fong GC, Luk KD, Yip B, Lee MK, Wong MS, Lu DD, Chan TK. A genetic locus for adolescent idiopathic scoliosis linked to chromosome 19p13.3. Am J Hum Genet 2002; 71:401-406.

15. Miller $\mathrm{NH}$, Justice $\mathrm{CM}$, Marosy $\mathrm{B}$, Doheny KF, Pugh E, Zhang J,Dietz HC 3rd, Wilson AF. Identification of candidate regions for familial idiopathic scoliosis. Spine (Phila Pa 1976) 2005; 30:1181-1187.

16. Lerner AB, Case JD, Takahashi Y. Isolation of melatonin and 5-methoxyindole3-acetic acid from bovine pineal glands. J Biol Chem 1960; 235:1992-1997.

17. Thillard MJ. [Vertebral column deformities following epiphysectomy in the chick]. C R Hebd Seances Acad Sci 1959; 248:1238-1240.

18. von Gall C, Stehle JH, Weaver DR. Mammalian melatonin receptors: Molecular biology and signal transduction. Cell Tissue Res 2002; 309:151-162.

19. Morcuende JA, Minhas R, Dolan L, Stevens J, Beck J, Wang $\mathrm{K}$, Weinstein SL, Sheffield V. Allelic variants of human melatonin $\mathrm{IA}$ receptor in patients with familial adolescent idiopathic scoliosis. Spine (Phila Pa 1976) 2003; 28:2025-2028, 2029.

20. Qiu XS, Tang NL, Yeung HY, Lee KM, Hung VW, Ng BK, Ma SL, Kwok RH, Qin L, Qiu Y, Cheng JC. Melatonin receptor ${ }_{1} \mathrm{~B}(\mathrm{MTNR} \mathrm{B})$ gene polymorphism is associated with the occurrence of adolescent idiopathic scoliosis. Spine (Phila Pa 1976) 2007; 32:1748-1753.

21. Nelson LM, Ward K, Ogilvie JW. Genetic variants in melatonin synthesis and signaling pathway are not associated with adolescent idiopathic scoliosis. Spine (Phila Pa 1976) 2011; 36:37-40.

22. Takahashi $\mathrm{Y}$, Matsumoto $\mathrm{M}$, Karasugi $\mathrm{T}$, Watanabe K, Chiba K, Kawakami N, Tsuji T, Uno K, Suzuki T, Ito M, Sudo H, Minami S, Kotani T, Kono K, Yanagida H. Lack of association between adolescent idiopathic scoliosis and previously reported single nucleotide polymorphisms in MATN $1, M T N R 1 B, T P H_{1}$, and IGFl in a Japanese population.] Orthop Res 2011; 29:1055-1058.

23. Qiu XS, Tang NL, Yeung HY, Qiu Y, Qin $\mathrm{L}$, Lee KM, Cheng JC. The role of melatonin receptor $1 B$ gene $\left(M T N R_{1} B\right)$ in adolescent idiopathic scoliosis--a genetic association study.Stud Health Technol Inform 2006; 123:3-8.

24. Salanti G, Sanderson S, Higgins JP. Obstacles and opportunities in meta-analysis of genetic association studies. Genet Med 2005; 7:13-20.

25. Moher D, Liberati A, Tetzlaff J, Altman DG. Preferred reporting items for systematic reviews and meta-analyses: The PRISMA statement. BMJ 2009; 339:b2535.

26. Ioannidis JP, Trikalinos TA. The appropriateness of asymmetry tests for publication bias in meta-analyses: A large survey. CMA] 2007; 176:1091-1096.

27. Morocz M, Czibula A, Grozer ZB, Szecsenyi A, Almos PZ, Rasko I, Illes T. Association study of $\mathrm{BMP}_{4}$, IL6, Leptin, $M M P_{3}$, and $M T N R_{1} B$ gene promoter polymorphisms and adolescent idiopathic scoliosis.Spine (Phila Pa 1976) 2011; 36:E123-E130.

28. Qiu XS, Deng LS, Yang XE, Zheng ZY, Qiu Y. The promoter polynmrphisms of melatonin receptor $1 \mathrm{~B}$ gene in adolescent idiopathic scoliosis. Chin J Pediatr Surg 2009; 30:869-872.

29. Oyama J, Murai I, Kanazawa K, Machida $M$. Bipedal ambulation induces experimental scoliosis in $\mathrm{C}_{57} \mathrm{BL} / 6 \mathrm{~J}$ mice with reduced plasma and pineal melatonin levels. J Pineal Res 2006; 40:219-224.

30. Xu L, Qiu X, Sun X, Mao S, Liu Z, Qiao J, Qiu Y. Potential genetic markers predicting the outcome of brace treatment in patients with adolescent idiopathic scoliosis. Eur Spine J 2011; 20:1757-1764.

31. Juni P, Holenstein F, Sterne J, Bartlett $C$, Egger M. Direction and impact of language bias in meta-analyses of controlled trials: Empirical study. Int J Epidemiol 2002; 31:115-123. 
